\title{
THE WEATHER IN THE ANTARCTIC
}

IN the recently published Meteorological Office 1 Geophysical Memoir No. 94*, Mr. H. H. Lamb reports on his work as meteorologist aboard the whale factory ship Balaena during the antarctic summer of 1946-47. The Balaena carried aircraft for spotting whales, and Mr. Lamb's task, so far as immediate operations were concerned, was to forecast weather and swell for the aircraft and the small whale-catching vessels. Broadcast observations were collected to compile once daily a synoptic map of much of the southern hemisphere, which was used in conjunction with local observation for the forecast work. No observations were received from other whaling vessels, and observations south of Australia, South Africa and South America were very scanty. Though meteorological observations have, of course, been taken in antarctic waters by numerous expeditions, it is believed Mr. Lamb operated the first weather-forecast service there.

It was found that knowledge of the structure and movements of pressure systems, air masses and fronts gained in the northern hemisphere was, after experience of the effects associated with the pack ice and topography of the Antarctic Continent had been gained, perfectly applicable in the Antarctic. Although the nearest reporting station was sometimes two thousand miles away, the forecasting work was very successful. Special attention in the forecasting work was paid to the sub-tropical anticyclones, as their positions and intensities largely determined the movements of the main warm-air steering currents of depressions. Care, too, had to be taken to maintain on the charts all fronts which might affect the ships. * Air Ministry: Meteorological Office. Geophysical Memoirs (M.O. 584b.) Bv H. H. Lamb. Pp. $68+5$ plates. (London: H.M.S.O. 1956.) 88 . 6 d. net.
The general weather over the Antarctic Ocean was very disturbed, with one depression soon following another and the only sunshine occurring in a break of a fow hours in the clouds every three or four days. As the cloud system of one depression moved away, the next could always be seen approaching. For a short period the ship was less than a hundred miles from the Antarctic Continent, and in off-shore winds the sky was sometimes quite clear. In spite of the great amount of cloud and the fact that there was rain or snow on 122 of the 151 days spent in the Antaretic, the precipitation measured $\mathrm{w}$ s only $43 \cdot 6 \mathrm{~mm}$. water, equivalent to an annual precipitation of 4 in. a year-a desert value. The value is not to be taken very exactly owing to the difficulty of giving only just enough heating current to the rain-gauge to melt the snow and no more, and also to loss of catch by the disturbance to airflow caused by the ship. Cumulo-nimbus clouds were frequent, and inversions only occurred occasionally.

The mean pressure south of $50^{\circ} \mathrm{S}$. was only $982 \mathrm{mb}$, and the maximum only $1013.4 \mathrm{mb}$. These values are much lower than over corresponding areas of the northern hemisphere and suggest that there is unequal sharing of air between the hemispheres. Mr. Lamb, using all the available information, gives in the memoir a mean pressure map of the southern hemisphere. This has a weak anticyclonic area over the Antarctic Continent (pressure about $1,000 \mathrm{mb}$. reduced to mean sea-level), a ring of depressions off the edge of the pask-ice of central pressures about $980 \mathrm{mb}$., and then a steady rise to the sub-tropical high-pressure belt in $30^{\circ} \mathrm{S}$. Daily weather maps show that the south polar anticyclones cannot be regarded as permanent and that the general situation over the Antarctic Continent is sometimes cyclonic.

\section{CONSERVATION OF FISHERIES}

A CONFERENCE on fisheries conservation was held in Rome during April 18-May 10, 1955, and was attended by delegates from forty-five countries. The conference was convened by the United Nations Organization in order to assist the International Law Commission in preparing draft articles on basic aspects of international law on fisheries, and a report was presented to the Commission in June 1955. The papers read at the conference have now been published*. They include important general contributions on fisheries resources and regulation by $M$. Graham, M. B. Schaefer, G. Belloc, W. C. Herrington, J. L. Krask, G. L. Kesteven and S. J. Holt, as well as summaries of actual international conservation problems such as the North Sea fisheries (C. E. Lucas), the Pacific halibut (H. A. Dunlop) and the Fraser River salmon (L. A. Royal). That it should be possible to control and conserve such diverse fishes indicates how much scientific knowledge has advanced in recent years.

Mr. Graham stresses that T. H. Huxley's dictumlet the fisherman be free-should be followed unless there is evidence that fishing activities are seriously

- Papers presented at the International Technical Conference on the Conservation of the Living Resources of the Sea, Rome, April 18 to May 10, 1955. (United Nations Publication, 1956. II.B.1.) Pp

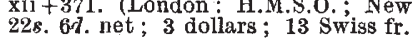

influencing the yield of a fishery. He points out that among the effects of over-fishing one must distinguish a decline in total yield from a decline in catch per unit effort or a decline in average size of fish. The latter two effects may not be a sufficient reason for regulating a fishery, although from economic causes (lack of recruitment of boys to the industry, no market for small fish) they may limit it. Dr. Schaefer expounds the whole theory of fishing and the equilibrium catch; and although he mentions the maximum economic cateh, it is apparent that he regards the production of the maximum sustainable yield as the main object of conservation. This thesis underlies most North American fishery regulation; but the maximum yield does not seem to have been obtained yet from the Pacific halibut. From Dr. Schaefer's own contribution on the tropical tunas, it would seem that high catches of yellowfin tuna near the limit of sustainable yield during 1948-51 resulted in an economic regulation of the fishery to a lower level in later years. In the North Sea all three effects of over-fishing have been experienced, and the recent international agreement on mesh sizes goes only part of the way to solve the problem.

Other interesting papers deal with the influence of the environment (J. B. Tait), the behaviour of fishes in relation to the environment (M. Fujinaga, J. 
Furnestin, R. Muzinic, A. J. (.. Jensen, R. Kändler, 'T. A. Kow, G. Ranson, G. Rollefsen and W. F. Royce), the productivity of the sea and the possibility of acclimatizing certain species in parts of the world outside their present range (I. Zenkevich). Some contributions from the Italian, Japanese and Korean delegations are frankly political and seom out of place in a scientific report. However, they illustrate how important marine-produced proteins may be in the national diet of many countries. To some oxtent this importance may explain the apparent disregard of the conference report at the meetings of the International Law Commission in May and June this year. It is to bo hopod that the reported draft articles on fisheries law, particularly that allowing a State to take unilateral action to regulate fisheries ou'side normal territorial waters, are being carefully scrutinized by the United Nations General Assembly.

A. J. SOUTHWARD

\section{GRANTS FOR DEVELOPMENT AND WELFARE IN THE BRITISH COLONIES}

$\mathrm{T}$

HE schemes made under the Colonial Dovelopment and Welfare Acts, covering the period April 1, 1955-March 31, 1956, which are detailed in the latest return*, bring the total commitments for development and welfaro schemes under the Acts to $£ 147,681,582$, and for resoarch schemes to $\mathfrak{1 4} 4,750,061$, of which $£ 27,909,965$ and $£ 1,889,486$, respectively, are for the year in question. Of this last sum, $£ 819,495$ is for agriculturo, $£ 332,701$ for medicine, $£ 281,182$ for social science, $£ 139,281$ for locust control, $\mathfrak{1 6 4 , 2 7 9}$ for insocticides, $£ 51,620$ for products research, $£ 19,241$ for economics research, $£ 10,880$ for tsetse and trypanosomiasis, $£ 3,510$ for fisheries and $£ 14,000$ for resoarch fellowships.

Of the actual research schemes, $\$ 362,000$ is for the Regional Research Centre for Agricultural Research in the Caribbean area, while a supplementary $£ 113,567$ goos to the Instituto for Social and Economic Research in the West Indies over the period 1956-60. $£ 59,905$ is capital expenditure for establishing the Fundamental and Applied Nutrition Units at the University College of the West Indies and $£ 42,570$ for the establishment and maintenance during 1955-58 of a Fundamental Nutrition Research Unit there. $£ 25,300$ is provided for soil and land-use survey in British Guiand, $£ 21,960$ for the maintenance of the Rockefeller Foundation Regional Virus Research Laboratory, Trinidad, and $£ 9,740$ for establishing seismic recording stations in the West Indies. In South-East Asia $£ 27,946$ is for filariasis research at the Institute for Medical Research, Kuala Lumpur, $£ 19,100$ for research in the Federation of Malaya on virus and other diseases transmissible from animals to man, and $£ 13,904$ for the appointmont of a plant pathologist investigating diseases of manilla hemp in North Borneo.

In Wost Africa $£ 43,100$ is for an agricultural improvement scheme in Gambia and a similar sum for the West African Building Research Institute,

* Colonial Development and Welfare Acts. Return of Schemes made under the Colonial Development and Welfare Acts by the Secretary of State for the Colonies, with the Coneurrence of the Treasury, in the Period from! 1st April, 1955, to 31st March, 1956.
$£ 20,000$ for the preparation of a social, political and economic history of the Benin, and $£ 11,000$ for extending the work of the Termite Rosearch Unit to West Africa. In East Africa £82,329 is for the East African Institute of Social Kesearch, Makerere College, Uganda, during 1956-60, $£ 38,100$ for the East African Virus Research Institute, $£ 34,000$ for the preparation of \& Flora of East Africa ; $£ 32,770$ goes to the Rhodes-Livingstone Institute, $£ 30,914$ to the Fast African Agriculture and Forestry Research Organization, $£ 22,596$ to the East African Veterinary

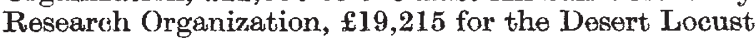
Survey and $£ 16,619$ for economic research at Makerere College. $£ 15,000$ was eontributed towards the activities of the Commission for Technical Cooperation in Africa South of the Sahara and the Sciontific Council for Africa South of the Sahara (a further $£ 30,000$ being provided from development and welfare schomes), whilo grants for general research schemes included $£ 60,350$ for research on animal physiology under tropical conditions at the Hannah Dairy Rosearch

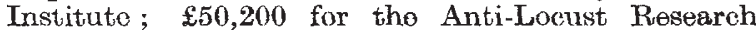
Centre during 1956 57 and a supplementary $£ 40,100$ during $1955-56$; $\$ 40,586$ for trachoma research in Jordan ; $£ 36,300$ for the Colonial Pesticides Research Unit, Porton, during 1956-60, and $£ 18,160$ for the 'T'ermites Researeh Unit during 1956 60.

Among the major development and welfare sehemes of particular scientific interest are the following:

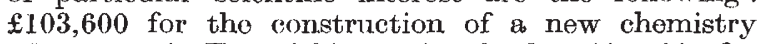
laboratory in East Africa and a further $£ 107,000$ for the construction of Nairobi Technical College; $£ 1,653,370$ for the intensification of African agricultural development; $£ 350,000$ for survey of the Rufiji Rivor, 'Tanganyika; $£ 328,875$ for the construction of trado schools and a technical institute in Tanganyika, and $£ 451,890$ for water devolopment and irrigation in Tanganyika. $£ 1,050,000$ is for the construction of permanent buildings for the University College of Rhodesia and Nyasaland, and $£ 48,000$ for the development of meteorological services for Central Africa. Of the contribution of $\{1,748,756$ to the development plan for the Northern Region of Nigeria during $1955-56, £ 274,628$ is for agriculture, $£ 117,514$ for technical education, $£ 338,243$ for modical services and health, $£ 548,168$ for rural water supplies, $£ 39,395$ for veterinary services, $£ 35,861$ for leprosy control and $£ 26,771$ for forestry. $£ 1,312,500$ has been provided for the development of rural water supplies in the Eastern Region of Nigeria, $£ 536,250$ for developing medical and health services; and of $£ 1,204,840$ for the development plan of the Western Puegion of Nigoria during $1955-56$, 245,210 is for agriculture, $£ 548,810$ for modical services and health, $£ 92,010$ for technical education, $£ 43,070$ for leprosy control, $£ 33,270$ for vetorinary services, $£ 24,570$ for forestry, and $£ 49,600$ for rural water supplies. $£ 115,530$ is for the devolopment of medical services and $£ 149,278$ for soil conservation in Basutoland, $£ 83,724$ for development of surface water supplies in Bechuanaland Protectorate, £113,185 for rural development and soil consorvation in Swaziland; $£ 82,000$ for agriculture and forostry development in St. Helena ;

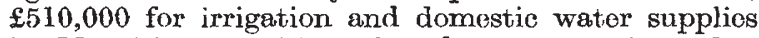
in Mauritius; $£ 80,781$ for the construction of a pathology building for the University of Hong Kong ; $£ 984,000$ for the construction of permanent buildings for the University of Malaya; $£ 50,000$ for aerial survey in British Guiana; and $£ 45,000$ for construction of a chemical laboratory in Jamaica. 